\title{
PREPARING FUTURE GENERATIONS OF LAWYERS FOR LEGAL PRACTICE: WHAT'S SUPERVISION GOT TO DO WITH IT?
}

\author{
JEFF GIDDINGS $^{*}$ AND MICHAEL MCNAMARA**
}

\section{INTRODUCTION}

This article considers the pivotal role played by supervision in the conduct of legal practice. While the supervision of work undertaken by junior practitioners, trainees and paralegals underpins the processes used in modern law offices, the structures that support such practices have not been closely analysed in the scholarly literature on the practice of law in Australia. Supervision arrangements have always been important to the practice of law and legal education. Arguably, this has never been more so than in current times with increasing numbers of graduates seeking to enter the profession, often with less in the way of practicebased experience than in the past.

We argue for a more structured approach to supervision in terms of both: (a) integrating the development of effective supervision into the various stages of legal education; and (b) providing structure around the supervisory relationship via appropriate training for supervisors and implementation of appropriate supervision methods. As part of this argument, we report on some of the survey data from the Queensland Legal Services Commission's Supervision Practices Check.

Part II of this article outlines the important role supervision has played in the development of legal education. We highlight how experiential learning in legal practice has always depended on supervision. At the same time, problems associated with the supervision of articled clerks contributed to greater institutionalisation of legal education, in particular the rise of Practical Legal Training ('PLT') programs.

* Director of Professionalism and Professor of Law, Griffith Law School, Griffith University.

** PhD Candidate and Sessional Instructor, Griffith Law School, Griffith University.

The authors acknowledge the assistance of John Briton and Lyn Aitken in relation to the Legal Services Commission Supervision Practices Checks, along with Zoe Rathus for her contributions to research that has generated this article. We also acknowledge the helpful assistance of the three anonymous referees.

Naturally, none of those mentioned are responsible for any deficiencies in the article itself. 
Part III considers the three stages of the current legal education framework and the relevance of supervision to each stage. Part III also highlights the significance of the supervised legal practice period, following admission to the profession, as the culminating stage of legal education. We argue that this culminating stage is dependent on a sophisticated understanding of supervision.

Part IV introduces supervision as a defined field of study developed in other disciplines and grounded by sophisticated conceptions of the nature of supervision. We highlight the multiple functions of supervision with emphasis on its education and training dimensions, and foreshadow the important lessons legal practitioners can take from other professions.

Part V explains the background to the Queensland Legal Services Commission's Supervision Practices Check, and presents results and commentary on data pertaining to the educational and training issues considered in this article.

Part VI considers existing empirical research from other disciplines which reveals the nature of effective supervision and revisits the data from the Supervision Practices Check. We make general observations regarding the state of supervision in legal practice.

\section{THE HISTORICAL LINK BETWEEN SUPERVISION AND LEGAL EDUCATION}

\section{A Origins and Early Reforms}

'Unacademic and informal' training has been a key aspect of legal training at least since the period of the Roman Republic. ${ }^{1}$ Commenting on the system of legal education in Ancient Rome, Atkinson highlights how supervision legitimises informal training:

But the sort of close supervision of a young man's studies which is described for us by Cicero, and which can be shown to be typical, cannot be regarded as 'informal' without danger of creating a misleading impression. It was in fact admirably calculated to combine general culture and theoretical speculation with the beginnings of practical experience. ${ }^{2}$

In the English common law system, supervision of lawyers-in-training has been a crucial yet troublesome component of legal education since the medieval period. University instruction in English common law was not available until the $18^{\text {th }}$ century. ${ }^{3}$ Until this time, 'an experiential, practical approach'

1 Kathleen M T Atkinson, 'The Education of the Lawyer in Ancient Rome' (1970) 87 South African Law Journal 31.

2 Ibid 35-6.

3 Legal instruction was available at Oxford and Cambridge much earlier but that was in canon law and Roman law: see Jonathan Rose, 'The Legal Profession in Medieval England: A History of Regulation' (1998) 48 Syracuse Law Review 1, 31. 
dominated. ${ }^{4}$ Central to this approach was on-the-job learning where instruction and supervision were provided to apprentices, not only by senior lawyers, but also judges. ${ }^{5}$

By the $15^{\text {th }}$ century, pleaders (the precursor to the barristers' branch of the profession) were educated through an experiential approach centred on the Inns of Court. The Inns of Court were a communal arrangement where apprentices lived together with qualified barristers, received lectures and engaged in moots. ${ }^{6}$ Eventually the practitioners whom the system relied on became prosperous and too busy such that the educational system in the Inns of Court declined to a standstill in the latter part of the $17^{\text {th }}$ century. ${ }^{7}$ Consequently, formal training of barristers remained dormant until the second half of the $19^{\text {th }}$ century. Disney et al neatly summarise the demise of the Inns of Court experiential system of learning:

The prosperity of practitioners encouraged their acquiescence. Many found that the demands of their practices made it difficult to find time for the preparation of readings. The readings declined, therefore, both in number and quality. An attempt was made by the Inns and the judges in the second half of the $17^{\text {th }}$ century to restore the old methods and to exact compliance with them. Benchers who refused to read were punished and orders were issued for the performance of exercises. These attempts however had no permanent effect and the last reading at Lincoln's Inn took place in $1677 \ldots 8$

Medieval training for attorneys (the precursor to the solicitors' branch of the profession) was less formal compared to the education system for barristers (which developed into, and eventually centred on, the Inns of Court). The out-ofcourt experiential system of education which existed for aspirant medieval attorneys has been characterised as a 'public academy', 9 and also involved lectures and practical training such as instruction in drafting writs. ${ }^{10}$ Some aspirant attorneys were also members of the Inns of Court or the other, less prestigious, Inns of Chancery. ${ }^{11}$

For solicitors, a formal five-year apprenticeship, where an aspiring solicitor was 'articled' to a qualified solicitor, was mandated as the admission requirement in England and Wales in 1729. ${ }^{12}$ The apprenticeship or articled clerkship was complemented by an examination system which, to begin with, 'amounted in practice to little more than an interview' with a judge, ${ }^{13}$ but slowly evolved in

$4 \quad$ Ibid 32.

$5 \quad$ Ibid 33.

6 Julian Disney et al, Lawyers (Lawbook, 2nd ed, 1986) 7-8.

7 Ibid 15-16, quoting Sir William Searle Holdsworth, A History of English Law (Little Brown, 1903-66) vol 6,481 .

8 Disney et al, above n $6,16$.

9 Rose, above n 3, 32.

10 Ibid 34.

11 Disney et al, above n 6, 10, quoting J H Baker, An Introduction to English Legal History (Butterworth, 2nd ed, 1979) 138.

12 Disney et al, above n 6, 21.

13 Ibid. 
strictness over the next 250 years while gradually being replaced by university legal education. ${ }^{14}$ By the mid-19 $9^{\text {th }}$ century, solicitors' lack of time to 'direct and supervise' students was identified as a shortcoming of the apprenticeship model of training..$^{15}$ Problems with supervision were an impetus for the development of formal legal education. The Australian colonies adopted the English system of requiring completion of an apprenticeship and passing examinations for admission purposes. ${ }^{16}$

\section{B The Shift to Institutional Learning of Law in Australia}

Australia's first law schools were established in Sydney and Melbourne in the 1850s. ${ }^{17}$ These law schools taught the 'academic theory of law' while practical training rested with the profession. ${ }^{18}$ The early law schools were small and comprised mainly of part-time academics who also practised law. ${ }^{19}$ This led to a close relationship between law faculties and the profession..$^{20}$ Despite the early presence of law schools in colonial Australia, only in the period after World War II did university become the predominant setting for legal education. ${ }^{21}$ By the 1980s, formal legal education was centred on poorly funded university classrooms with high student-faculty ratios. ${ }^{22}$

The development of the university law school as the dominant mode of legal education led to tension between the profession and the academy. The tension related principally to the preparation of lawyers for professional practice. While legal academics were preoccupied with critical, theoretical and doctrinal approaches to the law, ${ }^{23}$ legal practitioners were preoccupied with their own professional practices with little time to teach professional skills and values via appropriate supervision.

This tension, never fully resolved, contributed to the instigation of PLT programs following the recommendations of the Martin Report in $1964 .{ }^{24}$ In relation to the shift from articles to PLT programs, Weisbrot has commented that:

The ascendency of the practical legal training courses had as much to do with concern over the inadequacy of the articles system as it did with the belief in the efficacy of formal, institutional training. The theory of articles, as with other apprenticeship training, was that articled clerks were given an early introduction to

14 Ibid 21-2.

15 Ibid 22

16 Committee on the Future of Tertiary Education in Australia, Parliament of Australia, Tertiary Education in Australia: Report (1964) vol 2, [11.5], [11.9], [11.10] ('Martin Report').

17 Ainslie Lamb and John Littrich, Lawyers in Australia (Federation Press, 2nd ed, 2011) 24.

18 Ibid.

19 Ibid.

20 Ibid.

21 David Weisbrot, Australian Lawyers (Longman Cheshire, 1990) 120-1.

22 Ibid 126.

23 Lamb and Littrich, above n 17, 25-7.

24 Martin Report, above n 16, ch 11. 
office practices and procedures; experience in real life situations (rather than simulations); supervision by a master solicitor; exposure to a wide range of legal business; and sufficient time off to complete complementary part-time studies. The reality of articles was frequently quite different, however. Articled clerks were often assigned tedious, menial tasks, and their status and salaries reflected this. Supervision was often poor in the busier firms, and the range of work limited in the smaller firms. ${ }^{25}$

Despite the dominance of university based legal training in the post-war period, the five-year apprenticeship mode of entry to the profession remained significant in New South Wales and Queensland until the 1970s. ${ }^{26}$ Even for those who completed a university law degree, a shorter apprenticeship or an articled clerkship (which varied in duration depending on the state) remained an obligatory component of legal training for admission purposes and was completed concurrently with, or after, university education. ${ }^{27}$ However, such training has now been almost entirely replaced by PLT programs. ${ }^{28}$

Despite the ascendancy of PLT programs and the demise of articles, the implementation of PLT programs was never envisaged as a replacement for inservice training. The Martin Report argued that 'apprenticeship training by itself is unsatisfactory, and that such education is inefficient'. ${ }^{29}$ The recommendation for PLT programs to replace articles was made on the basis that there 'would still remain, however, the need for actual and supervised office practice in the handling of clients' affairs' ${ }^{30}$ Acceptance by PLT programs that they 'cannot act

25 Weisbrot, above 21, 149.

26 Ibid 121. Five-year articled clerkships remained an approved form of practical legal training leading to admission in Queensland until after the turn of the 21 st century. The Queensland Solicitors Board exams ceased in 1985. After this time it was still possible to gain admission by completing a five-year articled clerkship while concurrently completing a part-time external law degree with the Queensland University of Technology. Other forms of practical training were also available, including service as a judge's associate, judge's clerk, and employment as a managing clerk: see Centre for Legal Education, The Lawyers' Admission Handbook - Issue 5, August 1999 (Law Foundation of New South Wales, 1999) 3141. In NSW, it is still possible to complete the Legal Profession Admission Board's Diploma in Law course to fulfil academic requirements. However, graduates of that course still must complete a PLT program for admission purposes. The Admission Board's exams are now simply an alternative to completing the academic stage as part of an approved university degree. This current Diploma in Law is, therefore, not a continuation of the old apprenticeship system: see Legal Profession Admission Board (NSW), Curriculum $<$ http://www.lpab.justice.nsw.gov.au/lpab/legalprofession_current_dip_law_stud_curriculum.html .

27 Weisbrot, above 21,148-9.

28 Articles of clerkship are still available as alternatives to PLT in Queensland, Victoria and WA. However, only WA has retained that terminology: see Legal Practice Board of Western Australia, Articles of Clerkship $<$ http://admittance.lpbwa.org.au/Articles-of-Clerkship $>$. In Queensland this form of practical legal training is now called a 'traineeship': see Queensland Law Society, Traineeships $<$ http://www.qls.com.au/For_the_profession/Your_legal_career/Studying_law/Required_study_training/T raineeships $>$. In Victoria, they are called 'supervised workplace training': see Law Institute of Victoria, Supervised Workplace Training <http://www.liv.asn.au/For-Lawyers/Careers-Centre/Admission-topractice/Supervised-Workplace-Training $>$.

29 Martin Report, above n 16, 60 [11.50] (emphasis added) (citations omitted).

30 Ibid 65 [11.69]. 
as a direct substitute for articles', ${ }^{31}$ and uncertainty around the academic efficacy of online delivery, ${ }^{32}$ reinforces the need for actual workplace training. The predominant mode of practical training in PLT programs is simulated activities. Although useful for teaching a wide range of skills, they 'are not a substitute for client instruction and supervision in a "real" setting'. ${ }^{33}$ Preparing law students to engage effectively in learning through supervision can begin much earlier. Universities, PLT providers and legal practitioners each have a role in a structured approach to supervision. A structured approach would also lessen future tension between stakeholders in preparing lawyers for professional practice.

\section{THE CURRENT LEGAL EDUCATION FRAMEWORK}

There have long been concerns about the lack of coherence in Australia's legal education framework, and the lack of integration between the academic phase undertaken as part of a university law degree and the vocational phase completed through a PLT program. Similar concerns have been expressed in relation to legal education in England. ${ }^{34}$ This Part considers how these different phases can collectively contribute to developing effective supervision practices.

\section{A How a University Law Degree Should Contribute to Developing a Structured Approach to Supervision and Professional Development}

The focus of admission bodies in their accreditation of university law degrees has been on ensuring coverage of particular areas of substantive law with no attention to the approaches used to foster student learning. ${ }^{35}$ These admission requirements are preoccupied with issues of content rather than pedagogy. It is important for law schools to maintain a strong focus on the development of

31 Dennis Pearce, Enid Campbell and Don Harding, Australian Law Schools: A Discipline Assessment for the Commonwealth Tertiary Education Commission - A Summary (Australian Government Publishing Service, 1987) 78.

32 Gaye T Lansdell, 'Have We "Pushed the Boat Out Too Far" in Providing Online Practical Legal Training? A Guide to Best Practices for Future Programs' (2009) 19 Legal Education Review 149.

33 Marilyn J Berger, 'A Comparative Study of British Barristers and American Legal Practice and Education' (1983) 5 Northwestern Journal of International Law \& Business 540, 580. In this discussion our reference to a 'law degree' includes all university degrees that fulfil the requirements of the academic stage of training, including undergraduate Bachelor of Laws ('LLB') degrees, graduate entry LLB degrees and graduate entry Juris Doctor ('JD') degrees.

34 Bob Hepple, 'The Renewal of the Liberal Law Degree' (1996) 55 Cambridge Law Journal 470, 471.

35 Mary Keyes and Richard Johnstone, 'Changing Legal Education: Rhetoric, Reality, and Prospects for the Future' (2004) 26 Sydney Law Review 537, 538. See also Vivienne Brand, 'Decline in the Reform of Law Teaching? The Impact of Policy Reforms in Tertiary Education' (1999) 10 Legal Education Review 109, 125-6; Richard Johnstone and Sumitra Vignaendra, 'Learning Outcomes and Curriculum Development in Law' (Report, Australian Universities Teaching Committee, January 2003) chs 1-2. 
graduate attributes, skills and theoretical perspectives. This educational focus should include fostering students' learning through structured reflection. One of the most effective ways in which to develop the frameworks and skills required for reflective practice is through working with supervisors and other teachers who can demonstrate and discuss this important process. ${ }^{36}$ This process of 'learning how to learn from experience' takes time. Working with supervisors who demonstrate and discuss relevant skills and insights enables the learner to incrementally develop their knowledge and abilities.

Study during a university law degree can play an important role in fostering effective approaches to supervisory relationships by introducing relevant concepts and highlighting their importance. This can be done by drawing on both the academic literature ${ }^{37}$ and materials developed by legal professional regulators ${ }^{38}$ which demonstrate the central role of supervision in addressing ethical issues. University law students should also engage with issues related to working in groups and developing leadership capacities. ${ }^{39}$ As part of this, students can usefully be encouraged to consider the dynamics of supervisory relationships.

Increasing numbers of university law students are being given the opportunity to participate in clinical legal education programs where they work closely with one or more supervisors, and this can deepen their understanding of the importance of supervision and the ways in which they can make supervision as constructive as possible. ${ }^{40}$ Students can be prepared for the processes of receiving feedback from supervisors as well as offering feedback to colleagues and supervisors. ${ }^{41}$ They can also be made aware of the common

36 Useful models for promoting structured reflection include the 4Rs process developed by Dr Mary Ryan and Michael Ryan: Mary Ryan and Michael Ryan, 'Developing a Systematic, Cross-faculty Approach to Teaching and Assessing Reflection in Higher Education' (Report, Australian Learning and Teaching Council, 2012) 18, Appendix A < http://www.olt.gov.au/resource-developing-systematic-crossdisciplinary-approach-teaching-and-assessing-reflective-writing $>$.

37 See, eg, Debra Lamb, 'Ethical Dilemmas: What Australian Lawyers Say About Them' in Stephen Parker and Charles Sampford (eds), Legal Ethics and Legal Practice: Contemporary Issues (Oxford University Press, 1995) 217. Supervision dimensions are involved in many of the ethical issues and dilemmas identified by the lawyers interviewed by Lamb.

38 See, eg, the Ethics Checks published by the Queensland Legal Services Commission: Legal Services Commission of Queensland, Ethics Checks for Law Firms $(25$ October 2013) <http://www.lsc.qld.gov.au/ projects/ethics-checks>.

39 The development of leadership capacities during formal legal education and training has gained momentum in recent years: see, eg, Paula Monopoli and Susan McCarty (eds), Law and Leadership: Integrating Leadership Studies into the Law School Curriculum (Ashgate, 2013).

40 Jeff Giddings, Promoting Justice Through Clinical Legal Education (Justice Press, 2013) 10-11. See also Kingsford Legal Centre, Clinical Legal Education Guide 2014 (2014) <http://www.klc.unsw.edu.au/ sites/klc.unsw.edu.au/files/55386_clinical_legal_education_guide_web.pdf $>$.

41 For an outline of useful practices in giving and receiving feedback, see Roy Stuckey et al, Best Practices for Legal Education: A Vision and a Road Map (Clinical Legal Education Association, 2007) 174-7. 
challenges associated with the process of supervision. ${ }^{42}$ Such awareness can then be developed further in subsequent stages of legal professional development.

\section{B Practical Legal Training and Preparation for Supervision}

As explained earlier, the preparation required of law graduates to gain admission to legal practice has dramatically changed. The traditional articles of clerkship have largely been replaced with PLT programs (offered by law schools and private providers).$^{43}$ PLT programs have been promoted as more effectively assuring the competency of novice legal practitioners.

The Competency Standards for Entry Level Lawyers that frame the content of PLT programs are concerned with competencies developed principally, if not entirely, through classroom-based programmed training. ${ }^{44}$ The current standards make no reference to workplace experience requirements, ${ }^{45}$ while the standards set to come into operation on 1 January 2015 only require a workplace experience of at least 15 days. ${ }^{46}$ There have been strong criticisms of the continuing heavy reliance on simulation exercises, ${ }^{47}$ while others have noted the significant limitations of unstructured learning in the workplace. ${ }^{48}$ The polarised nature of this 'simulation versus workplace' argument underplays the potential to effectively integrate learning in both contexts.

As mentioned earlier, one of the distinctive contributions made by students having the opportunity to learn through supervised work with clients is the

42 Processes for supervision are addressed in Adrian Evans et al, 'Best Practices: Australian Clinical Legal Education' (Report, Australian Government Office for Learning and Teaching, September 2012) 17-19. See also Liz Ryan Cole and Leah Wortham, 'Learning from Supervision' in J P Ogilvy et al (eds), Learning from Practice: A Professional Development Text for Legal Externs (Thomson West, 2nd ed, 2007) 31 .

43 See above Part II(B).

44 Allan Chay and Frances Gibson, 'Clinical Legal Education and Practical Legal Training' in Sally Kift et al (eds), Excellence and Innovation in Legal Education (LexisNexis Butterworths, 2011) 497, 519. They refer to classroom and online learning environments in which students can gain 'some or all of the benefits of experiential learning'.

45 Australasian Professional Legal Education Council, Law Admissions Consultative Committee, Competency Standards for Entry Level Lawyers (February 2002) <http://www.aplec.asn.au/Pdf/ Competency_Standards_for_Entry_Level_Lawyers.pdf $>$.

46 Law Admissions Consultative Committee, Practical Legal Training: Competency Standards for EntryLevel Lawyers (1 January 2015) $4<\mathrm{http} / / /$ wwwl.lawcouncil.asn.au/LACC/images/pdfs/LACC CompetencyStandardsforEntryLevelLawyers-Jan2015.pdf>.

47 Chay and Gibson, above n 44, 524, citing Christopher Roper, 'The Legal Practice Courses: Theoretical Frameworks and Models' (1988) 6 Journal of Professional Legal Education 77. See also Stephen Nathanson, 'Problem-Solving in Professional Legal Education' (1989) 7 Journal of Professional Legal Education 121.

48 Chay and Gibson, above n 44, 524, citing R J Condlin, 'Learning from Colleagues: A Case Study in the Relationship between "Academic" and "Ecological" Clinical Legal Education' (1997) 3 Clinical Law Review 337 and A Sherr, 'The Value of Experience in Legal Competence' (Paper presented at Australasian Professional Legal Education Conference - Skills Development for Tomorrow's Lawyers: Needs and Strategies, Sydney, 4-8 September 1996) vol 1, 133. 
development of frameworks for personal reflection. ${ }^{49}$ PLT programs should make the most of the opportunity presented to assist students to learn how to learn from experience..$^{50}$ The lack of coherence between some law degrees and PLT programs makes it more important that those charged with designing these programs make informed choices about the design, delivery and sequencing of experiential learning opportunities. ${ }^{51}$ The development of supervision arrangements that enable students and their supervisors to effectively harness the learning potential of practice experiences requires sustained engagement with the pedagogy of experiential learning.

Simulations offer a range of benefits and advantages as vehicles for learning. A key advantage is that simulations can provide a safer environment in which to prepare students, 'the learner can take risks which might produce disastrous results for a client in the real world and learn from them without causing harm'. ${ }^{52}$ There are also practical advantages in terms of avoiding space and time constraints. ${ }^{53}$ Such advantages are particularly significant for introductory activities, ${ }^{54}$ and in providing 'a transitional experience in which students may apply theoretical knowledge within a context of practical relevance'. ${ }^{55}$ It is important to recognise that there are also disadvantages of using simulations in preparing learners to take real responsibility for client interests in practice contexts. The artificiality of simulations can generate difficulties with learners

49 Chay and Gibson recognise the importance of reflective practices in enabling people who are learning in the workplace to 'obtain all the possible benefits they can from that activity': Chay and Gibson, above $n$ 44, 524.

50 For an outline of the benefits of an experiential approach to PLT, see ibid 523-4.

51 Exceptions to this lack of coherence include the integrated professional programs at Flinders University and the University of Newcastle. These programs enable students to complete their LLB and PLT studies as part of the same integrated program. In addition, a number of universities, including University of New South Wales, La Trobe University and Griffith University, offer internship programs as an elective for LLB/JD students. In these courses, students undertake a placement which is supplemented by small group seminars or tutorials where a number of professional issues, including supervision, are openly discussed.

52 Paul S Ferber, 'Adult Learning Theory and Simulations: Designing Simulations to Educate Lawyers' (2002) 9 Clinical Law Review 417, 431.

53 See Stephen T Maher, 'No Easy Walk to Freedom' (1992) 1 District of Columbia Law Review 243, 251. 'Student cases do not need to be covered by faculty during holidays and exam periods. The teacher, not the judge or the client, is in charge of the case'.

54 Maranville notes the 'ugly side' of the reality of legal practice: 'difficult clients, overly aggressive opposing counsel, intemperate judges, overwhelming workloads. Too much reality too soon, or a heavy dose of the down sides of reality can discourage rather than motivate students': Deborah Maranville, 'Passion, Context, and Lawyering Skills: Choosing among Simulated and Real Clinical Experiences' (2000) 7 Clinical Law Review 123, 134.

55 Karl Okamoto, 'Learning and Learning-To-Learn by Doing: Simulating Corporate Practice in Law School’ (1995) 45 Journal of Legal Education 498, 502. 
predisposed to doubt the relevance of the content. ${ }^{56}$ This increases the importance of effectively linking developmental simulation exercises to practice-based learning opportunities, during both university law degrees and PLT programs.

The diversity of placement requirements in PLT programs raises significant questions in relation to the contribution of such placements in the preparation of PLT students for their transition to supervised legal practice. While it is clear that PLT programs effectively structure the development of law graduates, ${ }^{57}$ the work experience requirements of PLT programs vary considerably in terms of duration and nature. A review of publicly available information on PLT programs revealed significant variation between programs in terms of placement duration, from two weeks to 16 weeks, as outlined in the table below. ${ }^{58}$

Placement Requirements for Practical Legal Training Programs

\begin{tabular}{|l|l|}
\hline Provider & Placement duration (weeks) \\
\hline University of Adelaide & 6 \\
\hline Australian National University & $4-16$ \\
\hline Bond University & 15 \\
\hline College of Law & $\begin{array}{l}5 \text { (if an additional clinical experience model is } \\
\text { completed), otherwise 15 }\end{array}$ \\
\hline Flinders University & Integrated in Bachelor of Laws ('LLB') \\
\hline Leo Cussen Centre for Law & 3 \\
\hline University of Newcastle & Included across LLB/PLT combined program \\
\hline Queensland University of Technology & 4 \\
\hline University of Tasmania & 2 \\
\hline University of Technology, Sydney & 16 \\
\hline University of Western Sydney & 9 \\
\hline
\end{tabular}

56 Philip G Schrag and Michael Meltsner, Reflections on Clinical Legal Education (Northeastern University Press, 1998) 16. Schrag and Meltsner encountered four problems with mini-simulations (legal practice role plays in which students played all the key roles): they were time-consuming for students; the students often struggled with playing non-lawyer roles; the 'facts' were often incomplete; and some students 'simply hated the role-playing': at 30-1.

57 For a comprehensive analysis of the merits of PLT programs, see John K de Groot, Producing a Competent Lawyer: Alternatives Available (Centre for Legal Education, 1995). See also Chay and Gibson, above $\mathrm{n} 44$.

58 These details were obtained from the public websites of each of the specified PLT providers, accessed during June/July 2014. Full details of the websites accessed are available from the authors. 
It is difficult to ascertain whether these PLT placements are effectively integrated with the rest of the program through a classroom component and opportunities for structured reflection. Placements tend to occur at the end of the program and, generally, do not appear to be systematically integrated with other program components. Some programs leave it to the student to secure their placement, and almost all permit students to claim credit for previous practicebased experience. In a range of instances, PLT programs appear not to harness the potential of supervised placement experiences as a key opportunity for students to better understand the dynamics of the practice of law. This is indicative of the lack of an integrated approach involving each of the stages of legal education in preparing law graduates for the challenges and opportunities involved in learning through supervised legal practice.

\section{Structuring the Supervision Provided in 'Supervised Legal Practice'}

This next section examines what we consider to be the least clearly understood stage of legal education, that of supervised legal practice. As outlined above, lack of systems to ensure effective supervision played a part in the demise of articles. ${ }^{59}$ This lack of supervision was calamitous because of the overall ad hoc nature of on-the-job training received as part of an articled clerkship. ${ }^{60}$ While articles have all but died, and pre-admission practical training has been condensed and institutionalised, this ad hoc system of on-the-job training remains. The supervised legal practice period is for all practical intents and purposes 'the new articles'. The main difference is that it occurs at the postadmission stage as opposed to the pre-admission stage. In other words, one side effect of the rise of the PLT system is that the ad hoc unstructured on-the-job training which occurred during articles has been shifted to the post-admission period (bar 2-16 weeks of placement experience). ${ }^{61}$

We now explore the purpose of the supervised legal practice period and confirm that it was intended to be a further stage of practical legal training. We also highlight the lack of structured arrangements supporting this stage of training.

\section{The Statutory Condition}

Supervised legal practice is a statutory requirement in all Australian states and territories. The legislation requires that newly admitted lawyers engage in

59 See above Part II(A) and Part II(B).

60 Specifically, 'it was perceived that articled clerks were, in many instances, receiving inadequate, or no, training or breadth of experience to qualify them as competent to practise': Lamb and Littrich, above $n$ 17,33 .

61 New legal practitioners subject to the supervised legal practice period do also have the benefits of the breadth of practical training obtained via a PLT program. 
supervised legal practice for two years (for those who have completed a PLT program) or 18 months (for those who have completed a traineeship). ${ }^{62}$

The term 'supervised legal practice' is not given any useful definition in the legislation. ${ }^{63}$ Nor has it been the subject of any useful judicial consideration. ${ }^{64}$ While supervised legal practice guidelines have been published by some law societies and regulators ${ }^{65}$ they provide virtually no practical guidance in relation to the meaning of supervision, appropriate supervision practices, or the training and developmental aspects of supervision. ${ }^{66}$

62 Legal Profession Act 2006 (ACT) s 50; Legal Profession Regulation 2007 (ACT) s 13; Legal Profession Act 2004 (NSW) s 53; Legal Profession Act (NT) s 73; Legal Profession Act 2007 (Qld) s 56; Legal Profession Act 2007 (Tas) s 59; Legal Profession Act 2004 (Vic) s 2.4.18; Legal Profession Act 2008 (WA) s 50. In SA, the requirement is not contained in the Legal Practitioners Act 1981 (SA) but in the Rules of the Legal Practitioners Education and Admission Council 2004 (SA) r 3.1.

63 Supervised legal practice hinges on the meaning of 'supervision', which is not defined in either the Australasian Parliamentary Counsel's Committee, Legal Profession - Model Laws Project: Model Bill (Model Provisions): 2nd Edition (August 2006) ('Model Bill for the Legal Profession') <http://www.pcc. gov.au/uniform/pcc-legal-prof-2006-d21.pdf>, or the Council of Australian Governments, Legal Profession National Law (31 May 2011) <http://www.justice.nsw.gov.au/Documents/LPR_Documents/ pdf/Legal_Profession_National_Law.pdf $>$ ('Legal Profession National Law').

64 A recent case before the Supreme Court of the ACT examined s 50 of the Legal Profession Act 2006 (ACT). However, the Court was not required to consider the provision in sufficient depth to make its finding useful to the meaning of supervision. The Court was only required to make a finding that the "the holder of an unrestricted practising certificate must be a person who is suitable to conduct a law practice as a principal and, other than as a supervised partner, to be qualified to engage in unsupervised legal practice': Barlow v Law Society of the Australian Capital Territory [2013] ACTSC 68, [73] (Refshauge, Burns and Marshall JJ).

65 See Legal Services Board of Victoria, Supervised Legal Practice Rules $2006<\mathrm{http}$ ://www.lsb.vic.gov.au/ documents/LSBSupervisedRules2006.pdf >; Legal Services Board of Victoria, Supervised Legal Practice Policy (March 2012) <http://www.lsb.vic.gov.au/documents/RRP_012_Supervised_Legal_Practice Policy_V1_(Mar_12).pdf>; Law Society of New South Wales, Supervised Legal Practice Guidelines $2014<\mathrm{http}$ //www.lawsociety.com.au/cs/groups/public/documents/internetregistry/661361.pdf>; Legal Practice Board of Western Australia, Supervised Legal Practice Guidelines (Legal Profession Act 2008) (25 September 2013) <http://practitioner.lpbwa.org.au/Restricted-Practice-and-Supervised-LegalPractice/Supervised-Legal-Practice-Guidelines-(Legal-Profession-Act-2008)>.

66 An exception is the Guide to Effective Supervision in Legal Practice, published by the Queensland Law Society, which provides a useful resource for practitioners: Queensland Law Society, Guide to Effective Supervision in Legal Practice: Practice Support (2010) <http://www.qls.com.au/files/a8a0b3c6-feeb45d0-91b4-a08500e39983/Effective_Supervision_in_Legal_Practice.pdf $>$. While this is a useful resource, it is not aimed directly at the supervised legal practice period. In addition, the guide includes a warning that it "has been prepared as an introduction to key considerations for effective supervision in modern legal practice, largely from a risk management and professional standards perspective, and is not intended as a comprehensive guide on personal supervision or leadership skills': at 2. Supervised legal practice has also been discussed regularly in legal profession publications which are useful but do not provide any systematic understanding of appropriate supervision during this stage: see, eg, Maree Westbrook, 'Supervised Legal Practice and the Legal Profession Act 2007' (2009) 29(5) Proctor 31; Malcolm Hinton, 'Supervised Legal Practice: New Administration Rule Helps CLCs and Others' (2006) 26(11) Proctor 28; Peter Byrnes, 'Supervised Legal Practice Requirements' (2004) 24(7) Proctor 19. 


\section{Beyond Practice Management: The Training Dimension}

Legal practitioners have largely treated supervision as a function of practice management, geared towards minimising risk, or as a tool for increasing productivity and profitability ${ }^{67} \mathrm{~A}$ broader view would recognise that supervised legal practice is a continuation of PLT and the culminating stage of legal education.

In 1994, the Law Council of Australia published a Blueprint for the Structure of the Legal Profession. ${ }^{68}$ The Blueprint clearly positioned the supervised legal practice period as a second stage of practical legal training and envisaged that it would include a 'program of professional training'. ${ }^{69}$ Similarly, the 'Legal Profession Reform: Green Paper', released by the Queensland government in 1999, envisaged 'compulsory academic or practical legal training for restricted practitioners and continuing legal education for unrestricted practitioners' ${ }^{70}$ To date there has been no formal connection between the content of a PLT program and the training received during the supervised legal practice period. In fact, the provision of training during the supervised legal practice period is virtually devoid of any profession-wide structure, with no benchmarking, skill development requirements or ethics requirements. This is in stark contrast to the vision at the time the Blueprint was created. The Blueprint described the professional training aspect of supervised legal practice as 'experience in prescribed field of practise; acquisition of prescribed legal practise skills; and understanding of prescribed areas of professional responsibility'. ${ }^{71}$ The Blueprint set out the requirements of each stage of training in terms of a number of principles. In relation to the supervised legal practice period, Principle Seven provided that:

An employed lawyer must demonstrate that each of the following skills has been acquired to an acceptable level of professional competence and diligence:

- interviewing and taking instructions;

- advising;

- legal research;

- fact investigation and case analysis;

67 Arthur G Greene, The Lawyer's Guide to Governing Your Firm (American Bar Association, 2009). Training and mentoring of associates is highlighted as an important issue in relation to firm profitability and employee productivity: at chs 10, 17. See also Michael Downey, Introduction to Law Firm Practice (American Bar Association, 2010) chs 40-1; Queensland Law Society, Guide to Effective Supervision in Legal Practice, above n 66; Law Society of England and Wales, Supervision Practice Note (6 October 2011) $<\mathrm{http} / /$ www.lawsociety.org.uk/advice/practice-notes/supervision/>; Law Society of Upper Canada, Employee Delegation and Supervision $<\mathrm{http}: / / w w w .1 s u c . o n . c a / E m p l o y e e D e l e g a t i o n a n d S u p e r v i s i o n />$.

68 Law Council of Australia, Blueprint for the Structure of the Legal Profession: A National Market for Legal Services (1994) ('Blueprint').

69 Ibid 8-9.

70 Queensland Government, 'Legal Profession Reform: Green Paper' (Research Brief No 2003/03 Parliamentary Library, Parliament of Queensland, June 1999) 14 [2.3].

71 Blueprint, above n 68, 9. 
- planning and carriage of legal matters;

- legal writing;

- legal drafting;

- advocacy or dispute resolution; and

- negotiation. $^{72}$

While most aspects of the Blueprint have been implemented to some extent, we have been unable to locate any evidence that implementation of Principle Seven has begun. There is no obvious reason why this is the case. In fact, supervised legal practice appears so overlooked that the supervised legal practice period is completely omitted in discussions or debates concerning the legal education framework. ${ }^{73}$ Newly admitted lawyers face uncertainty in terms of their post-admission professional development with their employers determining the types of professional training received. This is not to say that the types of skills referred to in Principle Seven will not be developed during the supervised legal practice period. Rather, the lack of structured engagement raises serious questions over the profession-wide development of future generations of legal practitioners. Even in cases where employers unilaterally provide worthwhile professional training to newly admitted lawyers, there is no guarantee that this training will follow on, pedagogically, from the first pre-admission stage of PLT. There is a substantial risk that training will be oriented in terms of employer needs rather than the needs of the junior practitioner and the profession.

Irrespective of the original intention of the supervised legal practice period, there is another reason why a broader, developmental approach to the supervised legal practice period should be preferred. Taking a narrow approach to the meaning of supervision (ie, an approach preoccupied with risk management) for the purpose of supervised legal practice makes little sense when looking at the overall legislative regime. The practice management and risk management dimensions of supervision are accounted for elsewhere in the legislative regime. Both the Model Bill for the Legal Profession ${ }^{74}$ and the Legal Profession National $L a w^{75}$ provide that principals of law firms are responsible for employees and deem principals of law firms liable for certain circumstances. Similarly rule 37 of

72 Ibid $10-11$.

73 See, eg, Law Admissions Consultative Committee, Submission No DR162 to Productivity Commission, Access to Justice Arrangements, 29 April 2014. Part 6 of that submission refers to three stages of legal education. The discussion of the third stage 'Continuing Professional Development' makes no mention whatsoever of the supervised legal practice period: at 12 .

74 Model Bill for the Legal Profession, above n 63, s 8.1.2. The Legal Profession Act and Regulations in all states and territories (except SA) are based on the Model Bill for the Legal Profession.

75 Legal Profession National Law, above n 63, ss 3.2.3-4. The Legal Professional National Law, now called the Legal Profession Uniform Law, has been passed by the NSW and Victorian parliaments but is yet to be proclaimed. When proclaimed it will supersede the existing legislation based on the Model Bill for the Legal Profession. 
the Australian Solicitors' Conduct Rules, ${ }^{76}$ which imposes a general duty to 'exercise reasonable supervision', is positioned as a component of practice management. ${ }^{77}$

In addition, much has been written about the dire state of the collective wellbeing of the legal profession. ${ }^{78}$ This tends to be attributed to the very nature of legal work. ${ }^{79}$ However, for junior lawyers, one identified cause of stress is the 'poor quality of mentoring and supervision in the first few years of practice' ${ }^{80}$ We suggest that an underlying factor is the failure to pay sufficient attention to the personal engagement underpinning the supervisory relationship. We note, however, that the relationship between effective supervision and wellbeing is beyond the scope of this article. However, it is relevant here, in terms of our argument for a broad developmental approach to supervision and we flag this issue again in our conclusion as an area for further research.

\section{The Need for Greater Structure in Supervision}

We argue that the lack of frameworks to support effective practices calls into serious question the adequacy of the current rules in relation to supervised legal practice and supervision more generally. The above analysis outlines that the legal profession is faced with the following challenging realities:

76 Law Council of Australia, Australian Solicitors Conduct Rules (June 2011) <http://www.law council.asn.au/lawcouncil/images/LCA-PDF/a-Z-docs/AustralianSolicitorsConductRules.pdf $>$. The Australian Solicitors' Conduct Rules have already been adopted in Queensland, NSW and SA: see Queensland Law Society, Australian Solicitors Conduct Rules (1 June 2012) <http://ethics.qls.com.au/ content/ascr.html>; Law Society of South Australia, Australian Solicitors' Conduct Rules (1 July 2014) $<$ http://www.lawsocietysa.asn.au/LSSA/Lawyers/Publications/Solicitor_Conduct_Rules.aspx $>$; Law Society of New South Wales, Professional Conduct and Practice Rules 2013 (Solicitors' Rules) (1 January 2014) <http:/www.lawsociety.com.au/ForSolictors/professionalstandards/Ruleslegislation/ SolicitorsRules/index.htm $>$. Victoria and NT are currently in the process of adopting the new rules. The existing professional conduct rules in the ACT and WA contain similar rules: see Legal Profession (Solicitors) Rules 2007 (ACT) r 35; Legal Profession Conduct Rules 2010 (WA) r 17(4).

77 Interestingly, there is no guidance in the rules in relation to the correct application or interpretation of 'reasonable supervision'. This reflects a lack of engagement with the significance and complicated nature of supervision generally (not just in relation to supervised legal practice). The Queensland Law Society in its recently published commentary to those rules does, however, highlight certain risk management and disciplinary issues in relation to this rule: see Queensland Law Society, The Australian Solicitors Conduct Rules 2012 in Practice: A Commentary for Australian Legal Practitioners (1st ed, 2014).

78 For an overview, see Norm Kelk et al, 'Courting the Blues: Attitudes towards Depression in Australian Law Students and Lawyers' (Report, Brain and Mind Research Institute, University of Sydney, January 2009).

79 For a summary of attributed causes, see Christopher Kendall, 'Report on Psychological Distress and Depression in the Legal Profession' (Report, Council of the Law Society of Western Australia, March 2011) 5. See also Queensland Law Society, Guide to Effective Supervision in Legal Practice, above n 66 , 41-3.

80 Colin James, 'Lawyer Dissatisfaction, Emotional Intelligence and Clinical Legal Education' (2008) 18 Legal Education Review 123, 136. 
1. The contributions that a law degree can make to fostering effective supervision practices have not been closely examined. Clinical legal education has an important role to play in providing undergraduate students with opportunities to develop the reflective practices that will assist them in professional supervision contexts. ${ }^{81}$ However, it should be recognised that undergraduate clinical experiences are developmental and need to be reinforced with other practice-based learning.

2. Having been given responsibility for a central role in supporting the transition from novice to practitioner, PLT programs do not appear to make effective use of the learning potential of supervised placements through effectively integrating such placements with the other dimensions of their programs.

3. Supervised legal practice was intended to be a significant stage in the education of legal professionals, yet there appears to have been insufficient attention paid to identifying and developing practices that will make this stage as effective as possible.

4. The lack of close attention to the supervised legal practice stage is reflected in the current legislative regime where the meaning of the relevant legislative provisions depends on how the term 'supervision' is interpreted. Despite this, the relevant legislation does not define 'supervision'.

5. Despite the central place of supervision as a concept that underpins the activities of almost all law-related workplaces, the legal profession appears not to have developed its collective understanding of what makes for effective supervision in the development of novice and junior practitioners, and in legal practice more generally.

Fortunately, supervision concepts have been more comprehensively developed by other disciplines. The next part of the article provides an overview of the way other disciplines have conceived supervision.

\section{CONCEPTIONS OF SUPERVISION IN OTHER DISCIPLINES}

Although supervision arrangements have played a role in the preparation of lawyers since ancient times and, in the context of the common law tradition, since the medieval period, the legal profession has not developed a specific body of supervision literature. This stands in stark contrast to some relatively newer professions, particularly social work and the various branches of psychotherapy. In fact, supervision is so important to those fields that it has emerged 'as a

81 See Giddings, above n 40; Evans et al, above n 42. 
distinct area of study' ${ }^{82}$ Research identifying the 'nature of supervision' (as opposed to research identifying 'what supervision should be') ${ }^{83}$ has dominated this field and an overview of the research is provided immediately below in Part IV(A). Research identifying what supervision should be or 'effective supervision' has recently gained some traction and will be considered later in Part VI of this article.

In addition, supervision has long been an issue for managers and leaders in organisations. While there is a clear conceptual overlap between supervision as conceived by other professions and supervision in the management literature, there are also clear differences between the two. A brief overview of supervision, as conceived in the management and organisational behaviour literature, is outlined below in Part IV(B).

\section{A Other Professions}

Social work and psychotherapy are credited as having been the first professions to formalise supervision practices. ${ }^{84}$ However, Milne is careful to note that: 'Given the widespread use of the apprenticeship approach in society, exemplified by the learning of a trade or profession from a more skilled practitioner or employer, it seems likely that supervision has been practised since ancient times'. ${ }^{85}$ This is true for the legal profession. However, those longstanding practices have not been comprehensively studied or conceptualised.

Supervision in the field of social work emerged from a process at the end of the 19th century where: 'volunteer social workers gathered around experienced leaders and, through a process which has been likened to an apprenticeship, learned through observation and instruction' ${ }^{86}$ Supervision in psychoanalysis emerged in the early $20^{\text {th }}$ century from Freud's psychoanalytic school of practice and included, 'guided reading, ${ }^{87}$ 'word association tests', ${ }^{88}$ and 'psychoanalysis' of junior therapists. ${ }^{89}$ Davys and Beddoe distinguish these early forms of supervision in social work and psychotherapy by their respective emphases. Early social work supervision emphasised 'adherence to agency

82 Arpana G Inman and Nicholas Ladany, 'Research: The State of the Field' in Allen K Hess, Kathryn D Hess and Tanya H Hess (eds), Psychotherapy Supervision: Theory, Research, and Practice (Wiley, 2nd ed, 2008) 500, 500 .

83 Ming-sum Tsui, Social Work Supervision: Contexts and Concepts (SAGE Publications, 2005) 143.

84 Allyson Davys and Liz Beddoe, Best Practice in Professional Supervision: A Guide for the Helping Professions (Jessica Kingsley Publishers, 2010) 11-14; Meg Bond and Stevie Holland, Skills of Clinical Supervision for Nurses: A Practical Guide for Supervisees, Clinical Supervisors and Managers (Open University Press, 2nd ed, 2010) 27-30; Derek Milne, Evidence-Based Clinical Supervision: Principles and Practice (Wiley-Blackwell, 2009) 8.

85 Milne, above n 84, 5.

86 Davys and Beddoe, above n 84, 11.

87 Milne above n 84, 8.

88 Ibid.

89 Ibid 9. 
policy', ${ }^{90}$ whereas psychotherapy supervision concerned 'client work'. ${ }^{91}$ This early distinction revealed an ongoing conflict in supervisory activities between the needs of the supervisee and client on one hand, and the demands or requirements of organisations on the other. Supervision as a professional activity continued to develop in the first half of the $20^{\text {th }}$ century in social work along with the many psychotherapy-based professions and, by the mid- $20^{\text {th }}$ century, had become a 'clearly specified requirement' of training for psychologists. ${ }^{92}$ Eventually the field of counselling psychology 'established itself as a key developer and researcher of supervision theory and practice'.$^{93}$

Supervision is actually 'an umbrella term' ${ }^{94}$ which encompasses a number of related activities, ${ }^{95}$ and species of supervision. ${ }^{96}$ 'Clinical supervision' is the activity of principal focus in the professional literature. While it has been defined by a number of authors, Milne's definition of clinical supervision stands out as having been formulated following a rigorous review of existing empirical literature:

The formal provision, by approved supervisors, of a relationship-based education and training that is work-focused and which manages, supports, develops and evaluates the work of colleague/s. ... It therefore differs from related activities, such as mentoring and therapy, by incorporating an evaluative component ... and by being obligatory. The main methods that supervisors use are corrective feedback on the supervisees' performance, teaching and collaborative goal setting. ... The objectives of supervision are 'normative (e.g. case management and quality control issues), 'restorative' (e.g. encouraging emotional experiencing and processing) and 'formative' (e.g. maintaining and facilitating the supervisees' competence, and general effectiveness) ... ${ }^{97}$

Milne notes that this definition

embraces various supervision formats, professions, therapeutic orientations and stages of provision (pre-qualification and CPD). It excludes staff training,

90 Davys and Beddoe, above n 84, 11.

91 Ibid 12

92 Milne, above n 84, 6.

93 Davys and Beddoe, above n 84, 13.

94 John Fowler and John R Cutcliffe 'Clinical Supervision: Origins, Overviews and Rudiments' in John R Cutcliffe, Kristiina Hyrkäs and John Fowler (eds), Routledge Handbook of Clinical Supervision:

Fundamental International Themes (Routledge, 2011) 8, 11.

95 Eg, Fowler and Cutcliffe include 'clinical supervision', 'mentorship' and 'preceptorship' and 'reflective practice' as coming under the umbrella of supervision: ibid. Bond and Holland recognise these same four activities as well as 'coaching', 'supervised practice' and 'structured peer-support': Bond and Holland, above n 84, 22-3. Finally, 'therapy' has been described as a 'closely related concept': see Milne, above n 84, 11.

96 For example, Owen and Shohet distinguish between 'educational', 'managerial' and 'clinical supervision': David Owen and Robin Shohet, 'Introduction to Clinical Supervision' in David Owen and Robin Shohet (eds), Clinical Supervision in the Medical Profession: Structured Reflective Practice (Open University Press, 2012) 1, 7-8. Similarly, Hawkins and Shohet distinguish between 'tutorial supervision', 'training supervision', 'managerial supervision' and 'consultancy supervision': Peter Hawkins and Robin Shohet, Supervision in the Helping Professions (Open University Press, 4th ed, 2012) 65-6. 
consultancy, performance management, mentoring, coaching, and other variations on the supervision theme that do not satisfy the above definition. ${ }^{98}$

Davys and Beddoe use the term 'professional supervision', ${ }^{99}$ noting that it is 'context-dependant' and 'context-specific'. ${ }^{100}$ They also usefully and correctly point out that 'within many professions, codes of practice and registration requirements prescribe a schedule of supervision which may vary with experience and qualification'. ${ }^{101}$ The context of supervision, professional persuasion and individual preferences will impact the choice of model. From its beginnings in social work and psychotherapy, 'professional' or 'clinical' supervision models have been adopted by the medical, ${ }^{102}$ nursing, ${ }^{103}$ and allied health professions, ${ }^{104}$ but not law. This is remarkable given the statutory requirement of supervised legal practice for newly admitted practitioners.

Two common themes emerge from the various models and approaches to supervision. First, supervision has multiple standpoints and stakeholders. This is usefully illustrated by Hawkins and Shohet, who highlight that supervision involves, at a minimum, the following five elements:

- 'A supervisor';

- 'A supervisee';

- 'A client';

- 'A work context'; and

- 'The wider systemic context'. ${ }^{105}$

Secondly, there is a general consensus that supervision has three functions: mentoring/support, managerial/administrative, and educational/training. ${ }^{106}$ The extent to which each function is, or should be, emphasised varies across the different models. Perhaps most relevant to the supervised legal practice period is the educational/training function. In view of this, legal practitioners ought to

$98 \quad$ Ibid 16

99 The terms 'professional supervision' and 'clinical supervision' are often used interchangeably. One view is that 'Professional Supervision encompasses several subjects one being Clinical Supervision.':

Australian Counselling Association, ACA Policy Document on Professional Supervision (1 March 2013) $1<\mathrm{https}$ ://www.theaca.net.au/documents/ACA\%20Supervision\%20Policy\%202013.pdf $>$. Another view is that the difference is merely one of professional orientation with the terms being essentially synonymous: see John Carpenter et al, 'Effective Supervision in Social Work and Social Care' (Research Briefing No 43, Social Care Institute for Excellence, October 2012) 3. Here the term 'professional supervision' is used as being synonymous with 'clinical supervision': at 3 .

100 Davys and Beddoe, above n 84, 11-14.

101 Ibid 18.

102 See, eg, Owen and Shohet, above n 96.

103 See, eg, Bond and Holland, above n 84.

104 See, eg, John Driscoll, Practising Clinical Supervision: A Reflective Approach for Healthcare Professionals (Baillière Tindall, 2nd ed, 2006).

105 Hawkins and Shohet, above n 96, 86. Hawkins and Shohet's model, the 'Seven-Eyed Model', considers seven modes of supervision.

106 The nomenclature does, however, vary: see Hawkins and Shohet, above n 96, 62-5. 
garner greater awareness of developmental models of supervision which 'view supervision as an evolutionary process, and each stage of development has defined characteristics and skills' ${ }^{107}$

Another key aspect of supervision, as conceived by other professions, is the centrality of the supervisory relationship. In this regard, Milne notes that 'the relationship is the arena for supervision', and that there is 'strong evidence for its importance within human development'. ${ }^{108} \mathrm{We}$ argue that the relationship between supervisor and supervisee should be treated no less importantly in the context of legal practice. Lawyers frequently work in teams of people, often for large firms. Supervisory arrangements are impacted by factors external to the supervisory relationship. Supervision is associated with 'leverage' and profitability. ${ }^{109}$ In fact, the growth of large firms is underpinned by a tournament culture which relies on a transactional or mercantile view of the supervisory relationship. ${ }^{110}$ Rather than being moulded by external factors, supervision needs to be restored to its rightful place as an interpersonal endeavour. At the very core of the supervisory process is a relationship between two legal practitioners. We revisit the importance of the supervisory relationship in terms of 'effective' supervision in Part VI below.

Rather than treating supervision as an overarching endeavour in its own right centred on the supervisory relationship, as has been the case with other professions, lawyers have treated it as a subset of practice management. ${ }^{111}$ Conceivably, the argument could be mounted that the approach taken by other professions is not appropriate to the practice of the law. We take the view that there are certainly lessons to be learnt from other professions, even if certain aspects are not transferrable or adaptable to the legal profession. The extent to which inter-professional models can and should be applied to the legal profession is something which requires further systematic research. ${ }^{112}$ The question still remains as to what supervision is required in legal practice. Given the existing perceptions of supervision being a function of practice management, it may be

107 Robert Haynes, Gerald Corey and Patrice Moulton, Clinical Supervision in the Helping Professions: A Practical Guide (Brooks/Cole, 2003) 112.

108 Milne, above n 84, 93.

109 See Queensland Law Society, Guide to Effective Supervision in Legal Practice, above n 66. This includes numerous references to increasing profitability by engaging in effective supervision.

110 Marc Galanter and Thomas Palay, Tournament of Lawyers: The Transformation of the Big Law Firm (University of Chicago Press, 1991) 91-9.

111 See above nn 66-7 and accompanying text.

112 One of the authors, Michael McNamara, is completing a PhD which begins this process. The thesis will draw on an eclectic mix of literature, from within the legal profession and other fields, to develop a framework for understanding and assessing supervision practices in legal practice. The thesis will also utilise survey data from the Queensland Legal Services Commission to empirically assess Queensland lawyers' supervision practices. 
appropriate for lawyers to delve further into the fields of management and leadership to enhance their collective understanding of supervision. ${ }^{13}$

\section{B Management and Leadership Literature}

Supervision is positioned slightly differently in the management literature as compared to the other professional literature discussed in Part IV(A) above. While the other professional literature emphasises the multiple standpoints of supervision, including the relationship between supervisor and supervisee, the management literature centralises the role or position of the supervisor in an organisation. For example, 'supervisor' is commonly defined as being a firstlevel manager. ${ }^{114}$ Similarly, where supervision is conceptualised as a process, this is done in terms of being a layer of management, for example, 'management at the lowest level of the organization'. ${ }^{115}$ The overall purpose for a supervisor 'is to see that an organization meets its goals'. ${ }^{116}$

However, there are some common trends that emerge in both streams of literature. For example, focusing only on a risk management perspective neglects the meaning and purpose of supervision. Importantly, like the professional literature, the management literature emphasises that supervision is a multifunctional process. Commonly, the functions of supervisors are described in terms mirroring those of managers generally and include the planning, organising, commanding, coordinating and controlling functions described originally by Henri Fayol. ${ }^{117}$ These functions include the roles of: trainer, planner, scheduler, motivator, coach, controller, leader, and recruiter. ${ }^{118}$

Although leadership is subject to multiple interpretations, the contemporary conceptualisation of leadership focuses on one person's ability to influence others in a group. ${ }^{119}$ There are a number of different leadership theories, each with their own purpose and focus. The current focus in leadership theory is the impact individuals, at the apex of their organisations, have on the behaviour of others. ${ }^{120}$ However, this was not always the case. House and Aditya, in a comprehensive analysis of all major leadership theories, note that 'research

113 Rather than, or in addition to, just literature from other professions discussed in Part IV(A) above.

114 Samuel C Certo, Supervision: Concepts and Skill-Building (McGraw-Hill Irwin, 8th ed, 2013) 3-4.

115 Ibid 4.

116 Ibid.

117 Carlene Cassidy and Robert Kreitner, Supervision: Setting People Up for Success (South-Western Cengage Learning, 2010) 8; Certo, above n 114, 10-13; Edwin C Leonard Jr, Supervision: Concepts and Practices of Management (South-Western Cengage Learning, 12th ed, 2013) 10; John W Newstrom, Supervision: Managing for Results (McGraw-Hill, 10th ed, 2013) 2-3.

118 Cassidy and Kreitner, above n 117, 9-10.

119 See Stephen P Robbins et al, Organisational Behaviour (Pearson, 6th ed, 2011) 330; Peter G Northouse, Leadership: Theory and Practice (SAGE Publications, 6th ed, 2013) 2-6. Northouse defines leadership as 'a process whereby an individual influences a group of individuals to achieve a common goal': at 5 .

120 This is evident in the attention given to 'transformational leadership', which reflects the latest paradigm shift in leadership studies. 
through the 1970s was almost exclusively based on lower- and middle-level managers and almost exclusively concerned the manner in which they supervised their immediate subordinates' ${ }^{121}$ House and Aditya, therefore deemed it necessary to make the distinction between strategic and supervisory leadership. While '[s]trategic leadership is directed toward giving purpose, meaning, and guidance to organizations', ${ }^{122}$ 'supervisory leadership' has been defined as 'behaviour intended to provide guidance, support, and corrective feedback for the day-to-day activities of work unit members'. ${ }^{123}$

Interestingly, but perhaps unsurprisingly, the 'guidance', 'support' and 'corrective feedback' detailed in House and Aditya's definition of supervisory leadership closely parallel the mentoring/support, managerial/administrative, educational/training functions from the professional literature and the functions of a supervisor commonly described in the management literature. This 'common thread' highlights that supervision is a complex activity which draws on a range of skills.

We have already described how supervision is a critical link between legal training and legal practice. ${ }^{124}$ However, legal practitioners and academics have tended to pay only limited attention to what supervision actually is, or what it entails. The multifaceted and complex nature of supervision (as identified in other disciplines) makes it clear that legal practice supervision involves a range of activities worthy of close, detailed and systematic examination. The next part of this article seeks to contribute to building the collective understanding of supervision by examining, and commenting on, data collected from legal practitioners in Queensland in relation to their experiences of supervising and being supervised. The data was collected by the authority responsible for regulation of the Queensland legal profession, the Queensland Legal Services Commission, as part of a project in collaboration with the authors of this article. $^{125}$

\section{THE QLSC SURVEY: PUSHING AT AN OPEN DOOR}

The Supervision Practices Check ('Survey') is one of a suite of four 'ethics checks' for law firms conducted by the Queensland Legal Services Commission

121 Robert J House and Ram N Aditya, 'The Social Scientific Study of Leadership: Quo Vadis?' (1997) 23 Journal of Management 409,444 . This study is particularly useful in that it not only provides summary of leadership theories, but also the extent to which each theory has been validated by subsequent testing. Ibid.

123 Ibid 445

124 See above Part III(C).

125 The 2011 survey was developed in collaboration with Jeff Giddings. The 2013 survey used the same format with additional questions devised by Michael McNamara. 
('QLSC'). ${ }^{126}$ The 'ethics checks' are part of a program of proactive engagement to enhance standards of conduct and prevent complaints. The Survey was first conducted in 2011. The QLSC invited law firms with seven or more legal practitioners to complete a supervision practices survey. ${ }^{127}$ The 2011 survey was completed by 434 respondents. The survey data obtained by the QLSC provides a rich source of information regarding supervision practices. The survey was updated in 2013 and the QLSC again invited all law firms with seven or more legal practitioners to participate in a second round of the supervision practices survey. In addition, an e-newsletter was sent to over 9000 Queensland legal practitioners inviting them to participate. The 2013 survey was completed by 360 respondents.

The respondents from both the 2011 and 2013 version of the survey include a mix of legal practitioner and non-legal practitioner employees as well as a range of experience levels. Respondents were asked to identify as a supervisor, supervisee or both. Broadly, the survey was broken into questions for supervisors, questions for supervisees, and demographic questions for all respondents.

The 'ethics checks' were not designed primarily as a tool for external evaluation and research. Rather, these types of surveys have been described previously as a form of participatory action research. ${ }^{128}$ The nature and potential use of this type of survey data has been considered extensively elsewhere. ${ }^{129}$ In summary, this survey data can be used to cautiously draw inferences where: (a) 'the patterns and relationships in the data are so strong that it is unlikely they could be explained any other way'; ${ }^{130}$ and (b) 'to throw doubt on theories where patterns and relationships in the data are completely inconsistent with that

126 The other 'ethics checks' are the Workplace Culture Check, Billing Practices Check and Complaints Management Check. Results of these 'ethics checks' have been reported elsewhere in the literature. See Christine Parker and Linda Haller, 'Inside Running: Internal Complaints Management Practice and Regulation in the Legal Profession' (2010) 36(3) Monash University Law Review 217; Christine Parker and Lyn Aitken, 'The Queensland "Workplace Culture Check": Learning from Reflection on Ethics inside Law Firms' (2011) 24 Georgetown Journal of Legal Ethics 399; Christine Parker and David Ruschena, 'The Pressures of Billable Hours: Lessons from a Survey of Billing Practices inside Law Firms' (2011) 9 University of St Thomas Law Journal 619. In addition, the results, and general information in relation to the 'ethics checks', are available on the QLSC website: Legal Services Commission of Queensland, Ethics Checks for Law Firms - The Surveys (19 December 2013) $<$ https://www.lsc.qld.gov.au/ethics-checks/surveys $>$.

127 For full details, see Legal Services Commission of Queensland, Supervision Practices Results 2011 (29 June 2012) <https://www.lsc.qld.gov.au/projects/ethics-checks/survey-results/supervision-practicesresults>.

128 Parker and Aitken, above n 126, 410. The data utilised in this research was also survey data which had already been obtained by the Queensland Legal Services Commissioner. See also Parker and Haller, above n 126; Parker and Ruschena, above n 126.

129 Parker and Aitken, above n 126.

130 Ibid 416. 
theory'. ${ }^{131}$ The data has been analysed with these limitations in mind. It is not a comprehensive analysis of all of the survey results. Rather, it is a preliminary account of results of particular relevance to the issues addressed in this article. The data presented here is from the 2013 version of the survey only.

\section{A The Supervision Practices Check: Approaches to Supervision}

Question 12 of the Survey asked respondents to indicate whether their approach to supervision was primarily proactive or reactive. The results are shown in Table 1. More than two-thirds of respondents considered their approach to supervision to be proactive rather than reactive. At the same time, more than 95 per cent of supervisor respondents referred to having an 'open door' supervision policy with supervisees able to see them when they had problems. An open door policy relies on the capacity of staff to identify problems and issues in a timely manner, something that relies on the developmental aspect of supervision. Survey question 27 asked supervisors to identify which of several statements described how they supervise. The results are shown in Table 2. The responses suggest many supervisors are less concerned with the developmental dimensions of their role. Only one-third set aside a regular time to review workloads, prioritise work and deal with problem cases, while 38.4 per cent of respondents indicated that they meet the training needs of supervisees, or ensure they are met.

Table 1 - Approaches to Supervision

\begin{tabular}{|l|r|}
\hline Answer Options & Responses: Per Cent \& Number \\
\hline Proactive & $70.4 \%(95)$ \\
\hline Reactive & $29.6 \%(40)$ \\
\hline Total number of responses & 135 \\
\hline
\end{tabular}

131 Ibid. 
Table 2 - Personal Supervision Systems

\begin{tabular}{|l|r|}
\hline Answer Options & Responses: Per Cent \& Number \\
\hline $\begin{array}{l}\text { I have an open door policy and staff come to see me when they } \\
\text { have problems }\end{array}$ & $96.4 \%(108)$ \\
\hline I review work done and allocate new work & $75.9 \%(85)$ \\
\hline I update and share information with staff in my office & $74.1 \%(83)$ \\
\hline I monitor staff for fatigue, stress and other problems & $56.3 \%(63)$ \\
\hline I review/check all communications & $50.9 \%(57)$ \\
\hline I identify my supervisees' training needs & $46.4 \%(52)$ \\
\hline $\begin{array}{l}\text { I review central risk indicators (eg, no time recorded on file, unbilled } \\
\text { files, long hours, excessive time entries) }\end{array}$ & $43.8 \%(49)$ \\
\hline I meet the training needs of my supervisees, or ensure they are met & $38.4 \%(43)$ \\
\hline $\begin{array}{l}\text { I implement workflow systems to ensure or assist process } \\
\text { compliance }\end{array}$ & $33.9 \%(38)$ \\
\hline $\begin{array}{l}\text { I set aside a regular time to review workloads, prioritise work and } \\
\text { deal with problem cases }\end{array}$ & $33.9 \%(38)$ \\
\hline I inspect all files at regular intervals & $33.9 \%(38)$ \\
\hline I inspect sample client files at regular intervals & $29.5 \%(33)$ \\
\hline I monitor how staff engage in peer file review & $23.2 \%(26)$ \\
\hline I only inspect problem client files & $6.3 \%(7)$ \\
\hline Other (please specify) & 2 \\
\hline Total number of responses & 112 \\
\hline
\end{tabular}

\section{B The Supervision Practices Check: Finding Time for Supervision}

Survey question 10 sought responses about how much time was spent on supervision activities. The results are shown in Table 3 . The responses demonstrate the importance of supervision in the work of lawyers. Almost twothirds of respondents were spending 20 per cent or more of their time on supervision activities, while almost 90 per cent spent at least 10 per cent of their time on such responsibilities. Survey question 11 addressed the issue of whether supervisors prioritise their fee-earning duties or their supervision duties when scheduling their work. The results are shown in Table 4. Almost two-thirds of respondents prioritise their fee-earning duties, emphasising the importance of this part of legal work.

Survey question 14 sought information on how respondents found time for their supervision responsibilities. The results are shown in Table 5. Almost half of the respondents indicated that supervision time was not structured into their daily work schedule, with more than 40 per cent answering that it was up to them to find spare time for supervision. Further, less than one in five respondents 
indicated that their firm allocated time for their supervision responsibilities. We consider it surprising that such an important aspect of legal work was not aligned with the billing structures of many of the firms that responded to the survey.

Table 3 - Finding Time for Supervision: What percentage of your time do you spend on supervision activities?

\begin{tabular}{|l|r|}
\hline Answer Options & Responses: Per Cent \& Number \\
\hline$<10 \%$ & $10.9 \%(15)$ \\
\hline $10-20 \%$ & $23.9 \%(33)$ \\
\hline $20-30 \%$ & $30.4 \%(42)$ \\
\hline $30-40 \%$ & $11.6 \%(16)$ \\
\hline $40-50 \%$ & $6.5 \%(9)$ \\
\hline $50-60 \%$ & $6.5 \%(9)$ \\
\hline $60-70 \%$ & $5.1 \%(7)$ \\
\hline $70-80 \%$ & $2.2 \%(3)$ \\
\hline$>80 \%$ & $2.9 \%(4)$ \\
\hline Total number of responses & 138 \\
\hline
\end{tabular}

Table 4 - Finding Time for Supervision: What do you prioritise when you schedule your duties?

\begin{tabular}{|l|r|}
\hline Answer Options & Responses: Per Cent \& Number \\
\hline Your fee-earning duties & $64.2 \%(86)$ \\
\hline Your supervision duties & $35.8 \%(48)$ \\
\hline Total number of responses & 134 \\
\hline
\end{tabular}


Table 5 - Finding Time for Supervision: How do you find time for your supervision responsibilities? Please tick all that apply.

\begin{tabular}{|l|r|}
\hline Answer Options & Responses: Per Cent \& Number \\
\hline My firm allocates time to me for my supervision responsibilities & $17.8 \%(23)$ \\
\hline $\begin{array}{l}\text { I can incorporate supervision time into the time I bill clients because } \\
\text { I am overseeing the work of my supervisees on client matters }\end{array}$ & $32.6 \%(42)$ \\
\hline $\begin{array}{l}\text { I record supervision time but may reduce the time billed to the client } \\
\text { where my supervision was of repeated tasks (such as drafts of an } \\
\text { advice) }\end{array}$ & $36.4 \%(47)$ \\
\hline Time for supervision is not structured into a daily work schedule & $48.1 \%(62)$ \\
\hline It is up to me to find spare time for supervision & $42.6 \%(55)$ \\
\hline Other (please specify) & 9 \\
\hline Total number of responses & 129 \\
\hline
\end{tabular}

\section{The Supervision Practices Check: Preparation for the Supervisory Relationship}

Our focus on the contributions of supervised experiences in legal education meant we were interested to better understand the ways in which supervisors are prepared for this important and prominent responsibility, and therefore asked questions relating to how they have learnt about and developed as supervisors. We recognise that supervision practices can be developed both informally and formally, and sought details of the range of factors influencing their preparation for and approach to supervision.

\section{Supervisors}

Question 15 asked supervisors to list the ways in which they developed their supervision practices. The results are shown in Table 6. These responses suggest that supervisors recognise the importance of responding to the needs and preferences of their supervisees. They also indicate that informal learning about supervision is important to how these lawyers developed their individual approaches. Observation and emulation of the approaches encountered as a supervisee were significant, along with compliance with firm processes. Question 16 asked supervisors to rate the level of training they have had for supervision. The results are shown in Table 7 . It is clear from these responses that many of these supervisors considered the preparation they had received for this role to be less than adequate. On a scale of one to six, the most common ratings given for the adequacy of preparation for supervision were one (not at all) and two, accounting for more than half of all responses. The lowest numbers of responses were for the higher ratings given where supervisors felt prepared to a level sufficient to their needs. Overall, the mean rating out of six was 2.76. This preparation rating is closely related to the issue addressed in question 17, which asked supervisors what type of training they had received. The results are shown 
in Table 8 below. Responses revealed a strong focus on in-house discussions with reliance on management-related literature on supervision. Informal discussions were the most common form of training, with formal external programs undertaken by less than a third of respondents.

Table 6 - Preparation for the Supervisory Relationship: How did you develop your supervision practices? Please tick all that apply

\begin{tabular}{|l|r|}
\hline Answer Options & Responses: Per Cent \& Number \\
\hline $\begin{array}{l}\text { By responding to the needs or expressed preferences of my } \\
\text { supervisees }\end{array}$ & $62.8 \%(81)$ \\
\hline By watching others & $48.8 \%(63)$ \\
\hline By trial and error & $46.5 \%(60)$ \\
\hline By following my firm's policies and procedures & $45.7 \%(59)$ \\
\hline By emulating a previous supervisor & $43.4 \%(56)$ \\
\hline By emulating my current supervisor & $27.1 \%(35)$ \\
\hline $\begin{array}{l}\text { Are there any other ways in which you developed your supervision } \\
\text { practices? }\end{array}$ & 20 \\
\hline Total number of responses & 129 \\
\hline
\end{tabular}

Table 7 - Preparation for the Supervisory Relationship: Have you ever had training in supervision? Please rate the level of training you've had for your supervision duties.

\begin{tabular}{|l|r|}
\hline Answer Options & Responses: Per Cent \& Number \\
\hline 1 (Not at all) & $30.5 \%(40)$ \\
\hline $2 \ldots$ & $22.9 \%(30)$ \\
\hline $3 \ldots$ & $12.2 \%(16)$ \\
\hline $4 \ldots$ & $18.3 \%(24)$ \\
\hline $5 \ldots$ & $6.1 \%(8)$ \\
\hline 6 (To a level sufficient to your needs) & $9.9 \%(13)$ \\
\hline Total number of responses & 131 \\
\hline
\end{tabular}


Table 8 - Preparation for the Supervisory Relationship: If you undertake training to build your supervision skills, what sort of training do you receive? Tick all that apply

\begin{tabular}{|l|r|}
\hline Answer Options & Responses: Per Cent \& Number \\
\hline $\begin{array}{l}\text { In-house informal discussions generally in response to problems } \\
\text { seen as supervision issues }\end{array}$ & $52.8 \%(56)$ \\
\hline Reading management literature & $46.2 \%(49)$ \\
\hline External formal training at irregular intervals when available & $32.1 \%(34)$ \\
\hline In-house formal training provided by my firm & $30.2 \%(32)$ \\
\hline I regularly read publications and attend workshops on supervision & $22.6 \%(24)$ \\
\hline Other (please specify) & 9 \\
\hline External formal training at regular intervals & $7.5 \%(8)$ \\
\hline Total number of responses & 106 \\
\hline
\end{tabular}

\section{Supervisees}

Question 48 asked supervisees whether they had received training or guidance on how to work with their supervisor and, if so, the type of training or guidance. The results are shown in Table 9. The preparation of supervisees is recognised in the literature as important in terms of fostering constructive supervisory relationships. The importance of the supervisory relationship was reflected in the most common form of preparation being personal discussions with the supervisor. More than half of the respondents referred to this form of preparation. In contrast, just 30 per cent of respondents indicated that they had not received training or guidance in relation to constructive engagement with their supervisor.

Table 9: Preparation for the Supervisory Relationship: Have you received training or guidance on how to work constructively with your supervisor in any of the following ways?

\begin{tabular}{|l|r|}
\hline Answer Options & Responses: Per Cent \& Number \\
\hline Through personal discussion with my supervisor & $50.9 \%(84)$ \\
\hline Through other colleagues & $35.2 \%(58)$ \\
\hline I have not received training or guidance & $30.3 \%(50)$ \\
\hline Through in-house courses & $20.0 \%(33)$ \\
\hline Through reading helpful publications that I have found & $15.2 \%(25)$ \\
\hline Through induction training & $14.5 \%(24)$ \\
\hline Through external training courses & $7.9 \%(13)$ \\
\hline Other (please specify) & $3.0 \%(5)$ \\
\hline Total number of responses & 165 \\
\hline
\end{tabular}




\section{Key Messages}

The most widespread system or method of supervision is an 'open door policy', and this reflects a relatively unstructured approach to supervision. However, a significant majority of supervisors anomalously and contradictorily self-identify as being proactive in their approach to supervision. While clearly prominent in terms of time consumed, supervisory activities do not appear to be built into the routines of legal practice and are often viewed as subservient to feeearning duties. Preparation for the supervisory relationship, for both supervisors and supervisees, appears to be predominantly firm-dependant and insular. It might be described as myopic and appears not to fully draw on valuable research from other disciplines. We argue that such an approach insufficiently prepares supervisors for what is a complex interpersonal endeavour. We also argue that fee-earning duties impede the development of appropriate support structures around the supervisory relationship. We develop these arguments further in Part VI below after introducing additional literature from other fields which provide useful guidance on the nature of 'effective' supervision.

\section{EFFECTIVE SUPERVISION: THE CASE FOR MORE STRUCTURE}

We have argued that the legal profession has not yet engaged closely with both the theory and practice of supervision. Part IV highlighted the highly developed, empirically based conceptions of supervision offered by other professions. A systematic and structured approach to supervision is axiomatic to those conceptions of supervision. In addition, a common goal amongst the professions is to identify or describe 'effective' supervision. The nature of, and what constitutes, effective supervision is discussed in this section with reference to the survey data from the Supervision Practices Check outlined above.

There are a number of challenges for developing the evidence base for effective supervision. ${ }^{132}$ In light of these challenges, it is necessary to first ask and answer the following questions: Effective for whom? How do we prioritise the interests of the supervisor, the supervisee, and the client? Are we concerned with process or outcomes? In addition, empirically testing the effectiveness of supervision poses a number of methodological issues. ${ }^{133}$ In the face of these challenges, there is a 'smattering of supervision research resulting in the ability to draw only tentative conclusions'. ${ }^{134}$ The legal profession has been a notable

132 For an overview of the challenges, see Maggie Stanton and Christine Dunkley 'Effective Supervision: The Evidence Base' in David Owen and Robin Shohet (eds), Clinical Supervision in the Medical Profession: Structured Reflective Practice (Open University Press, 2012) 117, 119-20.

133 Inman and Ladany, above n 82, 501.

134 Ibid. 
absentee from this interdisciplinary field. The upside to the legal profession's inattention to supervision is that it can benefit from work already done by other professions. The conclusions from the evidence base, although only tentative, provide useful insights to which legal practitioners and academics should pay attention. The current empirical literature on effective supervision provides a number of indicators of effective or appropriate supervision.

These indicators are useful to legal practitioners, especially in terms of ensuring the supervised legal practice period meets its intended purpose. If properly understood and adapted for legal practice, they can provide guidelines for:

- Strengthening the personal engagement underpinning supervision; ${ }^{135}$ and

- Structuring the process of, and methods used, as part of any supervisory process. ${ }^{136}$

\section{A The Quality of the Supervisory Relationship}

As outlined above in Part IV(A), the relationship between supervisor and supervisee is central to supervision practices as conceived by other professions. In fact, the strength of the supervisory relationship is critical to the success of supervision. Following a comprehensive review of literature on effective supervision, Kilminster and Jolly concluded, in the context of clinical medical education, that ' $[\mathrm{t}] \mathrm{h}$ e quality of the relationship between supervisor and trainee is probably the single most important factor for effective supervision'. ${ }^{137}$ Similarly, in the context of psychotherapy supervision, Inman and Ladany note that the 'supervisory working alliance is at the heart of effective supervision'. ${ }^{138}$ Accordingly, in considering whether an aspect of supervision is effective, it is useful to consider whether it has a positive or negative impact on the supervisory relationship.

In this section we outline some specific factors which benefit the supervisory relationship, identify that an effective supervisory relationship will change over time, and argue that supervisors, without sufficient training, may be ill-equipped to usefully develop the supervisory relationship. Research on effective supervision from other professions indicates that the following, interpersonal factors will benefit the supervisory relationship:

135 See below Part VI(A).

136 See below Part VI(B).

137 S M Kilminster and B C Jolly, 'Effective Supervision in Clinical Practice Settings: A Literature Review' (2000) 34 Medical Education 827, 828.

138 Inman and Ladany, above n 82, 502. 
- An 'attractive' style of supervision which is characterised by a supervisor being 'warm, friendly, open and supportive toward their trainees'; ${ }^{139}$

- Similarly, if a supervisee experiences or perceives fear of negative impacts, this is associated with non-disclosure of important information which in turn negatively impacts the supervisory relationship; $;{ }^{140}$ and

- Supervisor self-disclosure. ${ }^{141}$ Essentially this will involve a supervisor revealing appropriate and genuine information about themselves to garner trust and allegiance.

Other empirical evidence from the professional literature indicates that the relationship should evolve over time. In particular, the level of guidance should depend on a supervisee's developmental level, ${ }^{142}$ and that 'the relationship between the supervisor and trainee changes as they gain experience.' ${ }^{143}$ In a general sense, this means that the approach to a particular supervisory relationship, to ensure its effectiveness, will depend on the supervisee. In Part IV(B) above, we introduced the potential usefulness of the management literature in developing an enriched understanding of supervision, in particular, theories of supervisory leadership. These theories complement the empirical evidence from the professional literature in relation to identifying the appropriate behaviour for effectively managing the interpersonal side of the supervisory relationship. Two theories of supervisory leadership are relevant here and are outlined below.

The contingency and situational theories predict outcomes of effectiveness based on certain circumstantial variables. In the case of contingency theory, these variables are leader-member relations, the nature of the task, and position/power of the leader. ${ }^{144}$ Among the various theories which consider situational factors, contingency theory has, largely, been validated by subsequent testing. ${ }^{145}$ In particular the hypothesis that 'task-motivated leaders perform best in situations of high and low control while relationship-motivated leaders perform best in moderate control situations ... has been amply supported'. ${ }^{146}$ Situational leadership theory considers the prescribed level of maturity of the supervisee as a variable which is linked to an appropriate style of supervision ('telling', 'selling', 'participation' or 'delegation'). ${ }^{147}$ Unlike contingency theory,

139 Nicholas Ladany, Jessica A Walker and Deborah S Melincoff, 'Supervisory Style: Its Relation to the Supervisory Working Alliance and Supervisor Self-Disclosure' (2001) 40 Counselor Education and Supervision 263, 263-4.

140 Inman and Ladany, above n 82, 506.

141 Ibid 502.

142 Ibid 506.

143 Kilminster and Jolly, above n 137, 834.

144 Robbins et al, above n 119, 335.

145 Ibid 336.

146 House and Aditya, above n 121, 422

147 Geir Thompson and Robert P Vecchio, 'Situational Leadership Theory: A Test of Three Versions' (2009) 20 Leadership Quarterly 837. 
situational leadership theory has not been substantially validated by subsequent empirical testing. ${ }^{148}$ However, 'there is some evidence to support the original theory's prescriptions for dealing with newer employees with greater directiveness,

and then substituting directiveness with supportiveness as employee seniority increases.' ${ }^{149}$ This prescription appears likely to be useful in considering the appropriateness of supervision practices during the supervised legal practice stage.

The literature confirms that, not only is supervision an interpersonal endeavour, but also that it is one undertaken at a very high level. We envisage an effective supervisor will be, amongst other things, a teacher who is highly attuned to the learner's capabilities at any given point in time and who is in possession of sufficiently developed interpersonal skills to fulfil a number of roles. This presupposes that an effective supervisor will have sufficient mastery over the legal work supervised to be able to determine exactly where a particular task fits, in terms of a supervisee's capability. It is not surprising then that other empirical research has found that:

- Supervision training matched with experience, not experience itself, is ideal for developing supervisors; ${ }^{150}$ and

- The need for training is widely accepted and there is some evidence that it can be effective. ${ }^{151}$

Therefore, given the high-level skills involved, it is unrealistic to expect that legal practitioners will develop the necessary supervision skills and understandings through their legal education and experience alone. Possession of technical legal skills and experience is necessary, but by no means sufficient for effective supervision.

As highlighted above in Part $\mathrm{V},{ }^{152}$ training received by a significant number of supervisors who completed the Supervision Practices Check was very limited and informal in nature. In Part IV(A) above, we introduced our argument that supervision in legal practice needs to be positioned as an important interpersonal relationship between supervisor and supervisee. This argument has been further developed in this section by pinpointing specific factors, grounded in the supervisory relationship, which impact the effectiveness of supervision. In summary, in terms of the strength of the supervisory relationship we raise the following issues:

148 Ibid 837.

149 Ibid 846.

150 Inman and Ladany, above n 82, 507.

151 Kilminster and Jolly, above n 137, 835.

152 See above Tables 6, 7 and 8 in Part V and accompanying text. 
1. Overall, it seems legal practitioners may have severely underestimated the interpersonal skills involved in supervision; and

2. The Supervision Practices Check data indicates that training of supervisors for this complex task is at best limited. We argue that legal practitioners should seriously consider implementing structured arrangements for the training of supervisors.

\section{B Providing Structure around the Supervisory Relationship}

In addition to the interpersonal factors discussed above, the supervisory relationship can be strengthened by providing appropriate structure around the process. Existing empirical research indicates that the relationship will benefit when it is supported by the following structures and systems:

- Continuity over time; ${ }^{153}$

- Reflection by both supervisor and supervisee; ${ }^{154}$

- The supervision process is separated from line management; ${ }^{155}$

- The supervisee has time for individual reflection; ${ }^{156}$

- Regular and frequent supervision; ${ }^{157}$ and

- Supervision contracts outlining expectations, role and responsibilities. ${ }^{158}$

Whether supervision is effective will also depend on the methods used. Milne selected 52 studies in which there was clear evidence that the supervision was educationally and clinically effective, and then identified the common supervision methods present in this sample of effective supervision scenarios. The 'common methods' identified by Milne can usefully be treated as key ingredients of educationally and clinically effective supervision. The five most common methods identified are: ${ }^{159}$

- Feedback (including praise and constructive criticism): 81 per cent of the studies;

- Observation and outcome monitoring: 79 per cent of the studies;

- Discussion (including providing a rationale, questions and answers, objective setting, problem solving, challenging supervisees thinking): 75 per cent of the studies;

153 Kilminster and Jolly, above n 137, 833.

154 Ibid.

155 Bond and Holland, above n 84, 250.

156 Ibid.

157 Carpenter et al, above n 99, 6. Here regular and frequent supervision is associated more generally with job satisfaction.

158 Stanton and Dunkley, above n 132, 117, 127.

159 Milne, above n 84, 120. 
- Written/verbal prompts and instructions (including guidelines): 48 per cent of the studies; and

- Encouraging autonomy (time management): 21 per cent of the studies.

Other methods present in the effective supervision scenarios were: formulation, modelling skills, behavioural rehearsal, and homework assignments (for example, guided reading). ${ }^{160}$ Although key to effective supervision, feedback alone is not sufficient. Feedback should be regular and ongoing. ${ }^{161}$ Formal reviews and performance management may be appropriate forums for some feedback, however, these formal processes should not be a substitute for 'realtime' feedback.

We argue that legal practitioners have also underestimated the complexity of supervision in terms of the appropriate structures and methods needed to make the process effective. As highlighted above in Part V, more than two-thirds of supervisors who responded to the Supervision Practices Check self-identified as having a proactive style of supervision. However, when the actual methods adopted by those supervisors are scrutinised, the 'open door' policy is clearly the most widespread method or system of supervision. In addition, the survey data suggests that the supervisory relationship may suffer due to external factors. While supervision is a time-sensitive exercise, it is de-prioritised behind feeearning duties and generally not factored into a day's legal work or supported in terms of law firm billing requirements.

These factors raise the following issues:

1. There is an inherent tension in relation to supervisors' self-identification as proactive and the reality of their actual supervision systems. It is not clear whether this self-identification is merely aspirational or whether it represents a fundamental misunderstanding of effective supervisory methods. If the latter, then this further strengthens our argument detailed in Part VI(A) in relation to the need to more effectively train supervisors.

2. The survey data suggests that supervision in legal practice is often ad hoc. It tends not to be structured around regular and frequent meetings. We argue that without frequent, regular and scheduled meetings, it is unlikely that appropriate methods will be applied systematically. It seems that systematic issues in relation to fee-earning and billing impede the development of effective structures.

160 Ibid.

161 Inman and Ladany, above n 82, 503. 


\section{CONCLUSION}

This article began with a historical review of the way supervision has impacted the development of legal education. This was followed by an examination of the stages of the current legal education framework and the importance of supervision in each stage. We highlighted that the supervised legal practice period has not fulfilled its intended purpose and pointed to the need for an enriched understanding of supervision in the context of legal practice. There was then discussion of the way in which other disciplines have conceived supervision. We have argued that legal practitioners appear to have treated supervision without the level of sophistication it deserves and that there is a need for greater structure in terms of integrating supervision in the legal education framework and developing the supervisory relationship.

First and foremost on the agenda for greater structure should be the training of supervisors. Given the complexity of the supervisory process, the benefits associated with training supervisors and the current limitations of supervisor training in the legal profession, an accreditation scheme for supervisors, as a means for fostering effective supervision practices, is a matter worthy of future debate. ${ }^{162}$ Secondly, legal practitioners need to seriously rethink the way they find time for, and provide structured support around, the supervisory relationship. Our argument for greater structure is supported by our analysis of some of the data from the Supervision Practices Check, along with our review of existing empirical research from other disciplines regarding the nature of effective supervision. Given the lack of existing research in the field of supervision in legal practice, our observations are necessarily general.

We have only examined specific aspects of the Supervision Practices Check data and there is a clear need for further research based on a more detailed examination of all of its aspects. Supervisory issues are potentially relevant to ethical behaviour more generally, and the relationship between effective supervision and ethical practice is a matter worthy of further systematic research. Interestingly in this regard, there are further lessons from the field of organisational behaviour regarding the potential benefits of 'supervisory ethical leadership'. ${ }^{163}$ Furthermore, as already foreshadowed, the relationship between effective supervision and the wellbeing of supervisees warrants further attention. The recently published Tristan Jepson Memorial Foundation Psychological Wellbeing: Best Practice Guidelines for the Legal Profession make numerous

162 For example, whether legal practitioners who supervise junior practitioners should be required to complete supervisor training as is the case for psychologists: see Australian Psychological Society, Psychology Board-Approved Supervisor Training <http://www.psychology.org.au/APSinstitute/ supervisor-training/>.

163 David M Mayer et al, 'Encouraging Employees to Report Unethical Conduct Internally: It Takes a Village' (2013) 121 Organizational Behavior and Human Decision Processes 89. 
references to supervision. ${ }^{164}$ The implementation of these guidelines by individual practitioners could be enhanced by an enriched understanding of supervision.

164 Tristan Jepson Memorial Foundation, Psychological Wellbeing: Best Practice Guidelines for the Legal Profession $<$ http://www.tjmf.org.au/wp-content/uploads/2014/05/TJMFMentalHealthGuidelines A4_140427.pdf>. 